TEME, г. XLV, бр. 1, јануар - март 2021, стр. 43-56

\begin{tabular}{lr}
\hline Оригинални научни рад & https://doi.org/10.22190/TEME200229004G \\
Примљено: 20. 2. 2020. & UDK 378:37.014.3]:316.647-057.875
\end{tabular}

Ревидирана верзија: 26. 9. 2020.

Одобрено за штампу: 26. 2. 2021.

\title{
STUDENT LEADERS ON BOLOGNA PROCESS IMPLEMENTATION - ADVANTAGES, SHORTCOMINGS AND PERSPECTIVES
}

\author{
Jelena Gajić*, Marina Savković, Dušan Borovčanin \\ Singidunum University, Belgrade, Serbia
}

\begin{abstract}
Almost two decades after the implementation of the Bologna Process in higher education around the world, the question of the applicability, justification and effectiveness of reforms implemented globally arises. The aim of this paper is to explore the attitudes, optimism versus pessimism, more precisely student representatives"mood" regarding the implementation of the Bologna Process and Bologna tools. The overall sample consists of student representatives from 17 European Higher Education Area countries. The results of the research should be a step towards further higher education reforms, or, more precisely, a proposal to modify the existing plans, bearing in mind the different conditions and characteristics of the countries where they are implemented and their willingness to accept the reforms. The results indicate that mobility, diploma supplements and quality assurance are the most positive aspects of BP and employability, the social dimension and the financing model of higher education are weak points of BP.
\end{abstract}

Key words: Bologna process, higher education, student leaders, shortcomings and perspectives.

\section{ПРИМЕНА БОЛОЊСКОГ ПРОЦЕСА \\ ИЗ УГЛА СТУДЕНТСКИХ ЛИДЕРА - ПРЕДНОСТИ, НЕДОСТАЦИ И ПЕРСПЕКТИВЕ}

Апстракт

Након скоро две деценије од почетка примене Болоњског процеса у високом образовању широм света, поставља се питање применљивости, оправданости и ефикасности спроведених реформи на општем нивоу. Циљ овог рада је да се истраже ставови, оптимизам/песимизам, тачније „расположење” студентских представника у вези са применом Болоњског процеса и инструмената. Укупан узорак чине студентски представници из 17 земаља Европског простора високог образовања. Требало би да резултати истраживања буду путоказ даљим реформама високог образова-

\footnotetext{
* Аутор за кореспонденцију: Јелена Гајић, Универзитет Сингидунум, Данијелова 32,
}

11000 Београд, Србија, jgajic@ singidunum.ac.rs 
ња, односно предлог модификације постојећих планова, имајући у виду различите услове и карактеристике земаља где се спроводе, као и спремност за прихватањем реформи. Резултати спроведеног истраживања указују на то да су мобилност, додатак дипломе и осигурање квалитета најпозитивнији аспекти Болоњског процеса, а запошљивост, социјална димензија и финансијски модел високог образовања су слабе стране Болоњског процеса.

Кључне речи: Болоњски процес, високо образовање, студентски лидери, недостаци и перспективе.

\section{INTRODUCTION}

The establishment of the European Higher Education Area (EHEA) was supported by the government, which is primarily interested in the impact of higher education co-operation on economic growth (Cippitani, Gatt, 2009). Furthermore, higher education institutions are intrested in improving quality and competitiveness (Klemenčić, 2019) in order to maintain the state's commitment to education as a public good, and to encourage students who emphasise the importance of equal opportunities, accessibility to higher education and student welfare as well as the employability of graduate students (through quality education).

Contemporary education development strategies are based on the concept of lifelong learning and the concept of a 'learning society'. These concepts were developed by international organizations in the 1970s and 1980s; The OECD, UNESCO, ILO, the Council of Europe and the European Commission, which define international development and the role of education and recommend them to their members as a basis for conducting national education policies (Masen, 2007). These concepts and expecations should be realistic and they certainly depend on the results of the adaptation or reforms (Neave, Veiga, 2012) in the educational systems of countries, in order for these countries to respond to changes, and to the new demands by improving the quality of the educational environment.

The specificities of countries in transition indicate the need for a quality model that will allow them to be aligned with their legal, political and economic characteristics. Higher education quality research in the European Higher Education Area is particularly viewed from the perspective of students, and their opinions and attitudes (Milojević, Radosavljević, 2019; Gajić, Živković, Stanić, 2017; Klemenčić, Chirikov, 2015; Gajić, 2012) are crucial in determining the quality of the system and establishing its control. The European Students' Union (ESU) conducted a survey with 11 million students in order to evaluate the results of the Bologna Process (BP) from the students' perspective in 2009. The results indicate a lack of progress in many aspects of the process, and there is a strong similarity to the survey from 2007. (BWSE. 2009; 7-15). In comparison to the survey from 2009, Bologna with Student Eyes surveys from (BWSE) 2015 and 2018 show that BP has 
become a higher priority for many governments, National Student Unions (NUS) and Higher Education Institutions (BWSE, 2009; 119).

As Klemenčić stated, the opportunity costs - both for individual students and our economies and societies - are enormous if higher education institutions do not fulfil their promise of formative effects on students (Klemenčić, Chirikov, 2015). This usually happens to be when institutions do not have a clear insight into what, why and how students learn and develop throughout their higher education. It is maybe too strong to say that we do not yet fully understand what is going on with students while they are enrolled in higher education as some authors argue (Klemenčić, Chirikov, 2015), especially if we know that student representatives have their legal representatives in Bologna Follow up Group. Ever since Prague Ministerial Summit in 2001., European Students' Union [ESU], the representative platform of the European national unions of students, has been granted a consultative membership and has participated in the governing structures of the Bologna process (Klemenčić, 2012). Therefore, the views and grades of student representatives are significant in order to realize the results of BP implementation and to make recommendations for further improvement of the process (Schomburg, Teichler, 2011; Kehm, 2010).

Comparing two series of 'Bologna with Student Eyes'surveys, in 2015\&2018, we can notice a decline in the students' impression of the positive impact of the Bologna Process on the student participation in their countries. At the beginning of the implementation of BP, most participants were enthusiastic but today, only two of them consider BP as a driving force for students; 16 stated that there is some influence and 19 do not see any effect or very little (European Students' Union 2012, 2015; BWSE 2015, 2018).

However, the test should refer to whether or not BP is trying to ensure student participation.

\section{SURVEY AND CONTRIBUTION}

The purpose of this research is to observe the progress and challenges of the Bologna process implementation and, through the attitudes of student representatives, indicate future development. The goal of this paper is to use the obtained results as inputs, recommendations for the modification or improvement of the Bologna process activities.

The online interview was conducted on the $30^{\text {th }}$ European Students' Convention and PASCL Second Annual Conference in Brussels, Belgium (2015). Student representatives from 17 EHEA countries (Netherlands, Switzerland, Norway, Belgium, Spain, Cyprus, Germany, Denmark, Azerbaijan, Croatia, Slovakia, the Republic of North Macedonia, Italy, Portugal, Montenegro, United Kingdom, Czech Republic) were interviewed. The interview guide contained questions with 1-5 scale $(1-$ not satisfied at 
all, 5 - fully satisfied), followed by open-end questions where representatives should give detailed answers and explain their gradings on the previous questions. The questions were related to the following elements of Bologna process implementation:

- Student participation in policy-making processes.

- The social dimension of the Bologna process.

- Quality assurance mechanisms implementation.

- Understanding and recognizing importance of ECTS concept.

- The contribution of the Bologna process to increasing mobility.

- Bologna process impact on employability.

- The financing model of EHEA.

- Optimism vs pesimism regarding further BP reforms.

The mainly qualitative method used and small sample in this research are seen as the basic limitations of the analysis. We tended to overcome them using a numerical scale for the answers and giving an overall grade for every analysed topic.

\section{RESULTS AND DISCUSSION}

Traditional EU members are more satisfied with different aspects of the Bologna process (average rating of 3.21), compared to new EU members (2.85), according to summary results analysis of all the answers (using average of the 1-5 scale). If we exclude Italy, whose student representative was very critically oriented towards most of the aspects of the Bologna process (average rating of 2.00), traditional EU members are even more satisfied with the process (3.37). EFTA members are also satisfied above the average (3.33). Candidate countries and Azerbeijan had an average rating of 3.12 .

Therefore, it is clear that new EU members are less satisfied than all other participants.

\section{The Most Commonly Mentioned Reasons for BP-Related Satisfaction or Dissatisfaction}

The factors that affect student representative satisfaction vary depending on the origin of the student. For example, Dutch representatives base their positive attitude on BP on the assessment that most of the goals have been implemented and that students have the ability to influence the development of the process itself. In Norway, according to their representative, "the significance and the design of learning outcomes are still not well understood at the grassroot level (students and academic staff". The incomplete realizations of EQF and NQF are the reasons for the dissatisfaction of Czech respondents. The representative of Germany emphasized that the Bologna Process had not been adequately supported by the management of Higher Education Institutions (HEI) and professors while 
the students from Slovenia did not notice significant changes except the new names of the subjects, which remained more or less the same.

Students from Spain said that Bologona Process has been successfulin terms of facilitating convergence and coherence with other European $H E$ systems, that has enabled and facilitated the internationalization and recognition of academic knowledge. However, the Bologna process implementation negatively affects economically disadvantaged students, since the tuition fees and lower student grants are some of the direct consequences of the Bologna process reforms.

Incomplete implementation in Croatia could be explained by the lack of management's and teaching staff's readiness to support changes in education. "There are almost no students who get a job after graduation and there is an opinion that if you want to complete your education you need to get a master's degree. This is a consequence of the extremely poor organization of undergraduate and graduate studies - instead of shortening from four to three years of undergraduate studies (before Bologna studies), most HEIs actually extended four years to five $(3+2)$, often, making postgraduate studies almost redundant."

In the Republic of North Macedonia students remarked that that there was no clear and precise measurement of BP implementation (similarly observed in Italy), and that Bologna is often seen as just a game for collecting ECTS.

Representatives of Cyprus, Montenegro, and Azerbeijan think that in their surroundings, BP is well received, students are completely familiar with the educational process, but at the same time they recognize more opportunities for progress. Danish students also rate the implementation of BP as successful, especially regarding structural issues, but they, however, claim that "challenges within the Social Dimension (SD) area still remain."

\section{Student Participation in Policy Making Process}

Considering the sample level, it can be concluded that student representatives clearly notice the difference between what is "written in the law" and what is actually expected to initiate and revive those letters.

Most respondents positively evaluate student participation in the policy-making processes at the faculty and university levels. Students' representatives from Norway, the Netherlands and Croatia expressed the highest degree of satisfaction. The representative of the Netherlands notes the importance of the partnership between students and the Ministry of Education. In Norway, legislation provides at least 20\% of student participation in all institutional bodies. Student participation in Croatia depends largely on the level of motivation and personal capacity of student council members. There is also a law in the Czech Republic that guarantees student participation at the national level in the decisionmaking processes; in Cyprus, the Student Union is the body that enables 
participation, and the situation is similar in the Republic of North Macedonia. However, all representatives, almost equally claim that students are present, sometimes "visible" but most often "not heard" - at least not to the extent that they think would be optimal. Respondents from Slovenia, Azerbeijan and Montenegro share this attitude (expectating a new law on higher education, the representative of Montenegro shows a little more optimism and enthusiasm).

The common issue for most of the participants in our research is the observation that at the national level there is insufficient space for their influence and voice. Some are very critical and precise in addressing responsibilities (Spain: "... in recent years, our government has marginalized and criminalized student movements, because of their political interests..."), others are somewhat milder but with a similar attitude (Denmark, Slovakia, UK, Germany). Respondents also recognize the other side of the problem, the need for all students to become more active and engaged more seriously (Italy: "...most students do not even know what Bologna is").

Compared with the results from BWSE 2018, there is a notable decrease in student participation (19 representatives stated that there was little or no effect, 16 that there was some influence, and only 2 considered $\mathrm{BP}$ as a positive driving force for student involment). In 2015, there were 10 unions and in 2012, 14 unions saw a significant positive impact on student participation. In 2018, there was a notable decrease considering the number of sudents participating in negotiation and brainstorming and student voice/participants in more informal arrangements. Many respondents were not satisfied with the transparency of the selection procedures of choosing student representatives ("they are not adequatly informed or selected"; France). In Italy, student representatives are constrained during the decision-making processes even though they hold seats on boards and senates; in Norway, students are satisfied with their participation in decision-making bodies but they want to improve participation inpreparatory work (BWSE, 2018).

\section{Positive Sides of BP Implementation}

According to student representatives, mobility enchancement is seen as the most positive result of BP (average grade 3,63). Although all respondents think that mobility is enchanced, their perception regarding the role of ECTS and recognition posibilities vary. In some cases, ECTS and recognition procedures are well-developed and stimulate further mobility of students (Netherlands, Cyprus). Some respondents mention difficulties of interinstitutional diploma recognition as the main barrier for student mobility (Norway, Germany, and the Chech Republic). There are noticeable differences among universities related to the intensity of student mobility (Italy). Respondents also mention universities which intentionally have restrictive recognition procedures, so they could control incoming mobility (the Re- 
public of North Macedonia, the Chech Republic, Denmark). In some cases, socio-economic backgrounds of students and relevant information accessibility still make a difference (Spain, Croatia, Portugal, the Republic of North Macedonia).

In some counties, the influence of Bologna on intensifying student mobility was extremely recognizable and advanced - in Montenegro, they are satisfied with mobility emphasizing it as a completely new experience; in Slovakia and Slovenia more students are using the term "privileged" students as they have this possibility.

Both students and staff mobility should be focused not only on numbers but also on the quality of mobility, which requires investments in IT, language learning for both international and local students (BWSE, 2018) monitoring mobility experiences, in order for the recognition and evaluation processes to operate fairly and for balanced mobility to flow. The Erasmus programme has been the source of funding for the mobility of up to 4.3 million young people between 2007 and 2016 (European Commission, 2018). European mobility programs have been intensively compared to those of 2008, so it can be said that education may not have been introduced at the national level as a public good, despite certainly being one.

Diploma supplements also seen as one of the successful points of BP implementation $(3,53)$. Good progress in the implementation od DS has been recorded since 2015 ("...one of these aspects has not been fulfiled and one country has not yet introduced the Diploma Supplement) (European Commission/EACEA/Eurydice, 2018, p.126). Compared to early stages of BP implementation (Klemenčić, 2006), quality assurance system is on a well-developed level $(3,32)$.

Regarding the accessibility of recognition of qualifications and credits, and the transparency of procedures, the situation slightly improved in 2018 if we are talking about automatic recognition. Students considered the lack of trust in validation procedures as the main obstacle to the development of recognition of prior learning, and it is probably a signal that indicates the necessity for reliable, detailed and transparent procedures (BWSE, 2018).

Most respondents agreed that the Quality Assurance (QA) mechanism had been fully or substantially implemented. In 2018, some kind of stagnation in the QA progress was recorded, even though the majority of students participated in internal and external QA and improving the quality of this involvement should be the required. The lack of information, transparency and the absence of relevant training were mentioned as the main barriers for students' involvement in QA process (BWSE, 2018).

Regarding the priorities of the Bologna process in the future, the European Students Union realize that the implementation needs to be is of highest priority for the next period (2018-2020) followed by Student 
Centred Learning (SCL) and Social Dimension (SD) of higher education (https://www.esu-online.org).

\section{Potentials for Improvement}

If we consider the particular aspects of Bologna process implementation, the lowest rating was given to the BP impact on employability (2.47). Student representatives think that BP does not have any influence on employability at all (Netherlands, the Chech Republic, Italy, Aserbaijan), or they are not informed about potential research on the topic (Germany, Norway). There are opinions that the Bologna process has destroyed the traditionally well-developed higher education system, so it has a negative influence on employability and labour market perspectives of young people (Croatia). The seemingly negative impact could be the result of a long economic recession, so it is difficult to mesure BP's isolated influence on employability (Denmark). At the same time, there is a strong belief that BP has had an indirect positive impact on employablity through transversal skills development and enchanced mobility for education and work (Spain and Cyprus).

Due to the long economic recession, the crisis of the national economy has been affected by unsatisfactory levels of student employability (Montenegro, Slovakia, Slovenia). "... in natural sciences, the situation is good, students can easily get a job. But with social sciences it is a much more difficult situation, there is a ban on employment in state institutions, there are many austerity measures in place. BP would have to focus more on practice and be more closely connected with the economy."

It can be said that there are still problems in policies promoting gradual employability and it is necessary to improve university cooperation with the labor market (European Commission/EACEA/Eurydice, 2018) to use labor market predictions, to engage employees in planning curricula, to provide incentives to include work placements in higher ediucation programs, to improve career development centers, to encourage/motivate student mobility and the implementation of Bologna tools (European Commission/EACEA/ Eurydice, 2018. p.240).

The Social Dimension of the Bologna process was also rated low $(2,79)$. Although in some cases everyone has access to higher education (Cyprus), student representatives move the focus from accessibility to retention, which is the challenge that keeps social inequality unchanged (UK). Students have some social and economic priviledges (Slovenia), but the social dimension is not a priority of the Bologna process, so nothing or not much has been done in this area (Belgium, Norway, the Chech Republic, Montenegro). In some cases, national grant systems have been deteriorated by BP (Netherlands), since economic recession has additionally worsened the position of students from low participation backgrounds (Spain). The result of the aforementioned challenges is that re- 
sources are still not spread equally (Slovakia). Almost all student representatives agree that it should be greatly improved, including representatives who are relatively satisfied with social services for students in their country (Germany, Azerbejan, the Republic of North Macedonia and Portugal). The most dissatisfied with this issue were the representatives of Italy.

The fact that the social dimension is recognized as a crucial issue within BP has not led to intensifying activities in order to make positive changes regarding this issue. Compared to the results from 2018, there are similar situations; 15 countries (out of 43) consider the Social Dimension as a high priority for HEI. Comparing 2015 and 2018, seven student representatives stated that "nothing has changed" during these years, and some of them (Poland, Iceland, Switzerland, Hungary, Belgum, Belarus and Ukraine) stated that SD is a low priority or not a priority at all; and only Denmark stressed that "it got worse" (BWA 2015, 2018).

As for the social dimension from Prague Communique (2001) to the Yerevan Communique (2015), even though it is one of the most important tools, only a few countries had taken action to improve the conditions underrepresented groups to access and complete higher education (European Commission/EACEA/Eurydice, 2018, p. 214).

Most respondents were not satisfied with the financing model of EHEA $(2,84)$. Being financed mainly on national levels, higher education institutions get the funding according to the number of students, not for the quality knowledge aquisiton processes and creativity enchancement (Norway, Croatia). "Education must be free for all students, no matter where they come from. Until then, we cannot support the financial model used in the EHEA. Everything is based on funding, as if universities were manufactories producing students..." (Norway). There is an opinion that commitments made throughout the Bologna process were not fulfiled by the decision makers on national levels (Denmark). Student representatives stress very difficult situations in particular EU countries where investments in higher education are noticeably below the OECD recommendations (the Chech Republic), or in those countries where an obvious deficit of university autonomy is present (Croatia).

A trend of discrimination against students with lower socio-economic status, disabilities and towards employed students (BWSE, 2009, 8) ${ }^{1}$ could be noticed, and it is still present.

${ }^{1}$ Only a few countries have created National Action Plans as effective instruments addressing the social dimension within the EHEA. They have usually been made without the participation and contribution of the student population, and the most effective plans involve the active participation of students in order to improve socio-economic conditions. 
Some Bologna Tools Are Demonstrating Good Results Regarding the

Creation of Equal European Higher Education Area (EHEA)

Student representatives from different countries have similar opinions regarding the implementation of Bologna tools - everyone agrees that the implementation depends largely on the country as well as on the particular university. The representatives of the Czech Republic, the Republic of North Macedonia, Croatia and Denmark are almost unique in this view, while representatives of other countries mention some more specific examples:

"Unfortunately, there is a lack of dealing with inequalities in investment in education, teaching and learning policies, the views of professors and academic staff." (Germany)

"Only a few countries have implemented Bologna tools correctly and systematically, others should be punished, perhaps excluded from the EHEA." (Norway)

"Diploma Supplement has not been implemented properly." (Spain)

\section{The Contribution of National Quality Framework (NQF) to the Creation of a Compatible European Higher Education Area (EHEA)}

Regarding NQF, 73\% of the total number of student representatives said that their countries had NQF. Students' attitudes from different countries vary considering their assessment of the importance of NQF in creating a compatible EHEA. In Germany, Spain, Azerbaijan, Montenegro and Croatia, students believe that this is the only and right way of development, while alternatives would require a large number of difficult bureaucratic procedures. Representatives from Belgium, Norway, Italy, Slovenia, Cyprus, Portugal and the Czech Republic are considering other approaches to the solution of creating a compatible EHEA. The Dutch representative insists on comparing grades and degrees.

\section{Understanding of the Concept of European Credit Transfer System (ECTS) by All Stakeholders in Higher Education (HE)}

According to our respondents, we can conclude that the attitude towards this issue is aligned with the level of the development of the state and society. Namely, there is a clear regularity - primary European members with stable economies (the views of the representatives of the Netherlands, Switzerland, Belgium, Denmark and Germany) are very similar, more precisely they have a positive attitude, estimating that everyone understands ECTS as they consider them logical and expected.

Other research participants show ambivalence (Spain), perceive inadequacy in implementation despite basic understanding (the Czech Republic, Norway), or give a "diplomatic" positive assessment with recommendations for additional efforts and further development (Cyprus, 
Azerbaijan).Representatives of Slovenia and Croatia estimate that this is a "pro-forma implementation", i.e. that the concept is essentially not fully accepted. The most critical views come from the Republic of North Macedonia, Italy, Montenegro and Portugal. Student representatives believe that "(almost) nobody understands anything, professors and academic staff, management of higher education institutions, students".

\section{Optimism vs Pessimism about the Future of Bologna in EHEA}

Despite the previously mentioned criticism, unfulfiled expectations and estimates that many aspects of the process could and should have been more successful, most respondents expressed optimism about the future of BP (72,2\% are opitimist versus $27,8 \%$ pessimist).

Some respondents expressed their belief that they should continue along the same lines, with a particular focus on the segments that were shown to have been improved (Cyprus, Azerbaijan, the Republic of North Macedonia) and a continuous exchange of experiences (Slovakia). They also insist on the distinction among thesingficance, strength and reach of the concept iself, with respect to irregularities or failures of implementation (Croatia). The represenative of Slovenia calls for more serious and comprehensive reforms "because only in this way can we provide a system that will be successful and long-lasting", while a similar view with more specific argumentation is made by the colleague from the Netherlands: ,so many differences in understanding and implementation of BP in different countries will lead to a loss of patience for those who were the first in the implementation. They will lose interest, they will look for another platform, so something really needs to change. The Czech representative insists on a unique solution and serious consideration of the current situation at the European level.

Scepticism about the future development of BP is present and some states politicians are thought to view education as a business using the same instruments of governance and goal realization (Norway). The Bologna platform has been used for university education reforms that have nothing to do with it; students have no awareness of what Bologna is and what it means. The only precise benefit is increased mobility, but it cannot be enough (Italy). Finally, there are concrete expectations of the near future of BP as a focus on two priority goals: the advancement of the social dimension and Student Centre Learning (Spain).

\section{CONCLUSION AND RECOMMENDATIONS}

Comparing the data from 2015 and 2018, we can notice that the same challenges for the implementation of Bologna reforms exist. The main challenges were the lack of resources, the lack of knowledge and the teachers' lack of interest. In this three-year period, some changes happened, 
and in 2018, the main challenge was the teachers' lack of interest, then the lack of resources and then the lack of knowledge (BWSE, 2018).

It is obvious that reforms of the Bologna system are necessary if we expect the system to be successful and sustainable in the long run. Since reforms include time and effort from all parties in the field of higher education, cooperation among the state, HEIs and students in all European countries, play a significant role in the achievement of common goals. Knowledge economies and knowledge societies confirm that higher education has a public responsibility and is strategically important for the future of Europe.

The research of the attitudes of student representatives from the European Higher Education Area countries regarding the implementation of the Bologna Process and Bologna tools indicates that the reforms were implemented with only limited/moderate success. Weak points of BP implementation are its impact on employability, the social dimension and the financing model of higher education. Mobility, diploma supplementand quality assurance are seen as the most positive aspects of BP and confirm that many activities have been done in the past 20 years and those include free movement of students and young workers, internationalization and quality assurance standards improvement.

Overall, the perception of student representatives is that the cooperation among universities and EU-funded programmes are the most positive sides of the Bologna process. On the other hand, there is a lack of understanding and commitment on national levels related to $\mathrm{BP}$ implementation issues, so universities are faced with insufficient and inappropriate funding. The weak social dimension (European Commission/ EACEA/Eurydice, 2018) of the Bologna process is also seen as "the guilty party" of the state and national policies. Finally, the connection of Bologna initiatives and employability is blurred.

As the results of the research show, reforms are not fully implemented in any signatory country. Moreover, there are a lot of cases where some of the reforms have been implemented partially and in form (Novaković, 2014), rather than in substance. But even though students are seeing many reforms fail, they still seem to be optimistic about the whole process. Certainly, the BWSE 2018 survey says that implementation must be the highest priority by 2020, followed by student-centred learning and the social dimension of higher education (paying attention to the BP implementation process itself rather than setting new goals), which opens space for further research in this area. 


\section{REFERENCES}

Aristotelis, Z. (2014). Global impacts of the Bologna Process: international perspectives, local particularities. Compare: A Journal of Comparative and International Education, 1-21.

Bologna with student eyes 2009 (2009). The European Students Union, Lueven, Belgium p. 8 .

Bologna with student eyes 2020 (2018). The European Students Union, Lueven, Belgium.

Cippitani, R. \& Gatt, S. (2009). Legal Developments and Problems of the Bologna Process within the European Higher Education Area and European Integration. Higher Education in Europe, 34, 385-397.

European Commission, E. H. (2015). ECTS Users' Guide. European Union.

European Commission/EACEA/Eurydice (2018). The European Higher Education Area in 2018: Bologna Process Implementation Report. Luxembourg: Publications Office of the European Union. p. 240

European Commission (2018). Commission staff working document, Mid-term evaluation of the Erasmus+programme (2014-2020). Report from the Commision to the European Parliament, The Council, The European Economic and Social Committee and the Committee of Regions Mid-term evaluation of the Erasmus+ programme (2014-2020), Brussels. 31.1.2018

Gajić, J., Živković, R., Stanić, N. (2017). Key Attributes of Successful Communication Between Higher Education Institution and Prospective Students, Teme, XLI(3), $557-572$.

Gajić, J. (2012). Importance of marketing mix in higher education institutions, Singidunum Journal of Applied Sciences, 9(1), 29 - 41.

Kehm, B. (2010). Quality in European Higher Education: The Influence of the Bologna process. Change: The Magazine of Higher Learning, 37-41.

Kehm, B., Huisman, J., \& Stensaker, B. (2009). The European Higher Education Area: Perspectives on a moving target. Roterdam: Sense.

Klemenčić, M. (2006). The Bologna process and student expectations. In Kohler, J., Purser, L. (eds.) Bologna Handbook - 1st Supplement (September 2006). European University Association and Raabe Academic Publishers. (book chapter).

Klemenčić, M. (2012). The changing conceptions of student participa-tion in HE governance in the EHEA. European Higher Education at the Crossroads, 631-653.

Klemenčić, M., \& Chirikov, I. (2015). How do we know how students experience higher education? On the use of student surveys. The European Higher Education Area , 361-379.

Milojević, R., Radosavljević, M., (2019). Assessment of Higher Education Service Quality: Integration of Servqual Model and AHP Method, Teme, XLIII (2), 557-577.

Overview on Student-Centred Learning in Higher Education in Europe (2015). Brussels: European Students' Union.

Schomburg, H., \& Teichler, U. (2011). Employability and Mobility of Bachelor. Roterdam: Sense Publishers.

Veiga, A. (2012). Bologna 2010. The Moment of Truth? European Journal of Education, 47(3), 378-391.

Veiga, A., \& Amaral, A. (2008). Survey on the implementation of the Bologna process in Portugal. Higher Education, 57-69.

YEREVAN COMMUNIQUÉ (2015). European Higher Education Area. 


\title{
ПРИМЕНА БОЛОЊСКОГ ПРОЦЕСА ИЗ УГЛА СТУДЕНТСКИХ ЛИДЕРА - ПРЕДНОСТИ, НЕДОСТАЦИ И ПЕРСПЕКТИВЕ
}

\author{
Јелена Гајић, Марина Савковић, Душан Боровчанин \\ Универзитет Сингидунум, Београд, Србија
}

\begin{abstract}
Резиме
Након двадесет година од потписивања Болоњске декларације, суочавамо се са различитим резултатима у поређењу са дефинисаним циљевима Болоњског процеса и напорима уложених у њену примену. Истраживање ставова високих студентских представника из земаља чланица Европске уније о примени Болоњског процеса указују на половичан успех спроведених реформи. Конкретно, $41 \%$ испитаника сагласило се да су све болоњске реформе спроведене, док се $40 \%$ њих сматра да спроведене реформе нису задовољавајућег квалитета. Главни изазови за спровођење Болоњског процеса су: отпор наставника у контексту спровођења реформи и промена, недостатак ресурса и недостатак знања/компетенција (BWSE, 2018). Резултати истраживања показују да је у контексту спровођења Болоњског процеса потребно унапредити: повећање фондова за инклузивнији приступ високом образовању у контексту обезбеђивања ресурса студентима лошијег материјалног статуса, успостављање структурне подршке за спровођење социјалне димензије студирања, примену концепта учења усмереног на студенте и целоживотног учења.

Мобилност, додатак дипломи и систем осигурања квалитета су најпозитивнији аспекти Болоњског процеса, док запошљивост, социјална димензија и национални модели финансирања високог образовања представљају слабу тачку Болоњског процеса. Могло би се рећи да фокус треба да буде на доследнијој примени усвојених образовних политика, учењу усмереном на студенте и социјалној димензији. Са друге стране, требало би избегавати усвајање нових циљева, као и додатних образовноадминистративних захтева и обавеза.

Због свега претходно наведеног, сматра се да владе, високошколске установе и друге организације треба да унапреде своју посвећеност примени Болоњског процеса и изградњи бољег међусобног разумевања и сарадње како би се постигло одрживо, инклузивно, висококвалитетно образовање широм Европе у европском простору високог образовања до 2030. године.
\end{abstract}

